\title{
Evidence for Enzymatic ADP-Ribosylation to Histidine and Related Dipeptides
}

\author{
Shuichi Tono-oka* and Ichiro Azuma
}

Section of Chemistry, Institute of Immunological Science, Hokkaido University, Kita 15-jo Nishi 7-chome, Kita-ku, Sapporo 060, Japan

\begin{abstract}
Tono-oka, S. and Azuma, I., 1994. Evidence for Enzymatic ADP-Ribosylation to Histidine and Related Dipeptides. - Acta Chem. Scand. 48: 780-782 (1) Acta Chemica Scandinavica 1994.
\end{abstract}

Interestingly mammalian tissue (spleen, brain, etc.)-derived $\mathrm{NAD}^{+}$glycohydrolase (NADase) [EC 3.2.2.5] catalyses, besides the ordinary hydrolysis of a quaternary nicotinamide-ribose glycosidic linkage of NAD ${ }^{+}$, transfer of ADP-ribosyl groups from $\mathrm{NAD}^{+}$to appropriate azoles as well as to pyridine derivatives. This enzyme has been found to exhibit an ADP-ribosyltransferase-like activity toward various types of target substrate, e.g., pyridines, ${ }^{1,2}$ indazoles, ${ }^{3}$ 1,2,4-triazoles, ${ }^{4}$ etc. On the other hand, ADP-ribosyltransferase activity specific for a proteinic substrate has been detected in human erythrocytes. ${ }^{5}$ Thus, in connection with haemocyte-derived enzymatic activity, it is of significance to examine further the transferase-like action of tissue-derived NADase on the constituents of protein, azole-type amino acid and related peptides.

In this study, we investigated porcine-brain NADasecatalysed ADP-ribosylation for histidine and related compounds together with some histidine-containing dipeptides and obtained ${ }^{1} \mathrm{H}$ NMR spectral evidence for their undergoing ADP-ribosylation.

\section{Results and discussion}

The enzymatic reaction was examined for L-histidine (1), L-histidinol (2), 4-hydroxymethylimidazole (3), histidylglycine (4), glycylhistidine (5), and histidylalanine (6). Each of compounds 1-6 and $\mathrm{NAD}^{+}$were incubated in the presence of NADase and the respective incubation mixtures were checked for the formation of possible ADP-ribosylated product by thin layer chromatography (TLC), and then the product was isolated by column chromatography on DEAE-Sephadex A-25.

A product in $45 \%$ yield $^{\dagger}$ from the incubation with 1 exhibited an intense $\left(M^{+}-1\right)$ ion peak at $m / z 695$ in the

\footnotetext{
* To whom correspondence should be addressed.

+ Based on NAD used.
}<smiles>[R7]CNCc1c[nH]cn1</smiles>

$1 \mathrm{R}^{1}=\mathrm{H} ; \mathrm{R}^{2}=\mathrm{CO}_{2} \mathrm{H}$

$2 \mathrm{R}^{1}=\mathrm{H} ; \mathrm{R}^{2}=\mathrm{CH}_{2} \mathrm{OH}$

$4 \mathrm{R}^{1}=\mathrm{H} ; \mathrm{R}^{2}=\mathrm{CONHCH}_{2} \mathrm{CO}_{2} \mathrm{H}$

$5 \mathrm{R}^{1}=\mathrm{COCH}_{2} \mathrm{NH}_{2} ; \mathrm{R}^{2}=\mathrm{CO}_{2} \mathrm{H}$

$6 \mathrm{R}^{1}=\mathrm{H} ; \mathrm{R}^{2}=\mathrm{CONHCH}\left(\mathrm{CH}_{3}\right) \mathrm{CO}_{2} \mathrm{H}$<smiles>OCc1c[nH]cn1</smiles>

3

negative FAB-MS spectrum, and showed, in the ${ }^{1} \mathrm{H}$ NMR spectrum, two anomeric protons ( $\delta 5.63$ and 6.08) as well as ten non-exchangeable protons $(\delta 4.12-4.41)$ of two riboses together with five non-exchangeable protons ( $\delta 3.02,3.17,3.92,7.27$ and 7.99 ) of histidine and two adenine-ring protons ( $\delta 8.19$ and 8.45 ), demonstrating that the product was ADP-ribosylated L-histidine (7).<smiles>[R7]CNCc1cn(C2OC(COP(=O)(O)O)C(O)C2O)cn1</smiles>

$7 \mathrm{R}^{1}=\mathrm{H} ; \mathrm{R}^{2}=\mathrm{CO}_{2} \mathrm{H}$

$8 \mathrm{R}^{1}=\mathrm{H} ; \mathrm{R}^{2}=\mathrm{CH}_{2} \mathrm{OH}$

$10 \mathrm{R}^{1}=\mathrm{H} ; \mathrm{R}^{2}=\mathrm{CONHCH}_{2} \mathrm{CO}_{2} \mathrm{H}$

$11 \mathrm{R}^{1}=\mathrm{COCH}_{2} \mathrm{NH}_{2} ; \mathrm{R}^{2}=\mathrm{CO}_{2} \mathrm{H}$

$12 \mathrm{R}^{1}=\mathrm{H} ; \mathrm{R}^{2}=\mathrm{CONHCH}\left(\mathrm{CH}_{3}\right) \mathrm{CO}_{2} \mathrm{H}$ 
This reaction occurred irrespective of the configuration ( $\mathrm{L}$ - or D-form) of histidine. Similar ADP-ribosylation was observed with 3, and an analogous dinucleotide 9 was isolated in $35 \%$ yield. Compound 2 seemed also to undergo the enzymatic ADP-ribosylation judging from TLC analysis, but virtually none of the desired product 8 could be isolated; this is presumably due to its instability during the isolation processes. In the case of respective reactions with dipeptides $\mathbf{4}$ and $\mathbf{5}$, corresponding new dinucleotides were formed and successfully isolated in $31-35 \%$ yield. They exhibited satisfactory mass and ${ }^{1} \mathrm{H}$ NMR spectral properties compatible with the structure of $\mathbf{1 0}$ and $\mathbf{1 1}$, respectively: in both cases, MS spectra showed $m / z 752$ $\left(M^{+}-1\right)$ and ${ }^{1} \mathrm{H}$ NMR spectra two doublets ( $\delta 5.96$ and 6.20) characteristic of two anomeric protons of the dinucleotides. In addition, dipeptide 6 was also found to undergo the enzymatic reaction, giving the ADP-ribosylated product 12 in $24 \%$ yield.

The ribosylation site in imidazole moiety of dinucleotides thus obtained was presumed to be exclusively the $N^{1}$-position, but not the $N^{3}$-position, on the basis of ${ }^{1} \mathrm{H}$ NMR spectral findings: the imidazole ring at the 5- as well as the 2-position showed lower-field resonances $(0.24-0.82 \mathrm{ppm})$ in all cases as compared with those in the corresponding substrate bases themselves. These are compatible with previous observations ${ }^{4}$ that an $\mathrm{N}$-atom bearing an adjacent bulky substituent does not readily undergo this enzymatic ADP-ribosylation. Thus, it has been shown here that the ADP-ribosylation to histidine and related dipeptides occurs by ADP-ribosyl transferase-like activity of porcine-brain NADase.

Recently 'NADase' has been noted in connection with its function associated with cellular signal transduction: new NADase activity catalysing, besides the normal hydrolysis of NAD to ADP-ribose and nicotinamide, the reversible conversion of NAD into cyclic ADP-ribose, was discovered in cell-surface CD38 antigen on human leukocytes ${ }^{6}$ and the cyclic NAD metabolite is suggested to play an important role in intracellular $\mathrm{Ca}^{2}+$ homeostasis. ${ }^{7}$ Although it is as yet unclear whether the tissuederived NADase has a similar function as the leukocytederived NADase and why the NADase exhibits nonspecific ADP-ribosyltransferase-like activity, it is noteworthy that porcine-brain NADase catalyses transADP-ribosylation from NAD to histidine and related dipeptides, as composition units of protein, as well.

\section{Experimental}

General. FAB-MS (negative) spectra were determined on a JEOL JMX-DX 300 instrument. The ${ }^{1} \mathrm{H}$ NMR spectra were recorded in $\mathrm{D}_{2} \mathrm{O}$ on a Bruker MSL-400 spectrometer (400 MHZ). Thin layer chromatography (TLC) was performed on silica gel $60 \mathrm{~F}_{254}$ HPTLC plates (Merck). Column chromatography was carried out on DEAESephadex A-25 and monitored by means of LKB Uvicord II $(254 \mathrm{~nm})$. Aqueous tris(hydroxymethyl)ami- nomethane-hydrochloric acid buffer solution (Tris$\mathrm{HCl} / \mathrm{pH} \mathrm{7.2)} \mathrm{was} \mathrm{used} \mathrm{as} \mathrm{the} \mathrm{incubation} \mathrm{system.} \mathrm{NAD}$ and dipeptides were obtained from Sigma, and L- and D-histidines, L-histidinol and 4-(hydroxymethyl)imidazole were from Aldrich.

Porcine-brain NADase [EC 3.2.2.5]. The crude particulate enzyme was prepared from fresh porcine brain by the method of Zatman et al. ${ }^{8}$ The colloidal homogenate containing ca. $0.4 \mathrm{U}^{\ddagger}$ per $\mathrm{ml}$ of NADase activity was used without further purification.

L-Histidine adenine dinucleotide (7) $\beta$-NAD (0.96 g, $1.4 \mathrm{mmol})$ and L-histidine $(0.82 \mathrm{~g}, 5.3 \mathrm{mmol})$ were incubated with NADase $(15 \mathrm{ml}, 6 \mathrm{U})$ in $0.2 \mathrm{M}$ Tris- $\mathrm{HCl}$ $(60 \mathrm{ml}, \mathrm{pH} 7.2)$ at $37^{\circ} \mathrm{C}$ for $26 \mathrm{~h}$. NAD disappeared at that point of incubation time. The reaction mixture was worked up in a similar manner as described previously. ${ }^{4}$ The crude mass $(0.85 \mathrm{~g})$ thus obtained was dissolved in water $(40 \mathrm{ml})$ and applied to a column of DEAE-Sephadex A-25 ( $\mathrm{HCO}_{3}{ }^{-}$form $)$. The column was washed with $0.8 \%(\mathrm{w} / \mathrm{w})$ aqueous $\mathrm{NH}_{4} \mathrm{HCO}_{3}$ solution and then eluted with a $4 \%$ solution of the same salt. The first eluted major component was ADP-ribose and the second major component was the desired product. The corresponding eluate fractions were collected and evaporated to dryness in vacuo to give a solid mass. The isolated mass was subjected to further chromatography and appropriate fractions were repeatedly lyophilized to give 7 (432 mg, 45\% yield) as a pale yellow ammonium salt. An analytical sample was obtained by further drying over $\mathrm{P}_{2} \mathrm{O}_{5}$ in vacuo at $40^{\circ} \mathrm{C}$ for $12 \mathrm{~h}$. MS: $m / z 695\left(M^{+}-1\right) .{ }^{1} \mathrm{H}$ NMR $\left(\mathrm{D}_{2} \mathrm{O}\right): \delta 3.02(1 \mathrm{H}, \mathrm{dd}, J 8.8$ and $15.4 \mathrm{~Hz}), 3.17(1 \mathrm{H}$, dd, $J 4.2$ and $15.4 \mathrm{~Hz}), 3.92(1 \mathrm{H}$, dd, $J 4.2$ and $8.8 \mathrm{~Hz})$, $4.12(2 \mathrm{H}$, br s), 4.22 ( $3 \mathrm{H}$, br $), 4.36(3 \mathrm{H}, \mathrm{br}), 4.41(1 \mathrm{H}$, $\mathrm{t}, J 5.0 \mathrm{~Hz}), 4.51(1 \mathrm{H}$, dd, $J 4.0$ and $5.0 \mathrm{~Hz}), 5.63(1 \mathrm{H}$, d, J $6.0 \mathrm{~Hz}), 6.08(1 \mathrm{H}, \mathrm{d}, J 5.9 \mathrm{~Hz}), 7.27(1 \mathrm{H}, \mathrm{s}), 7.99$ (1 H, s), $8.19(1 \mathrm{H}, \mathrm{s}), 8.45(1 \mathrm{H}, \mathrm{s})$. Anal. $\mathrm{C}_{21} \mathrm{H}_{30} \mathrm{~N}_{8} \mathrm{O}_{15} \mathrm{P}_{2} \cdot 2 \mathrm{NH}_{3} \cdot 2 \mathrm{H}_{2} \mathrm{O}: \mathrm{C}, \mathrm{H}, \mathrm{N}, \mathrm{P}$.

4-Hydroxymethylimidazole adenine dinucleotide (9) A mixture of 4-hydroxymethylimidazole (376 $\mathrm{mg}, 3.8 \mathrm{mmol}$ ) and NAD (725 mg, $1.1 \mathrm{mmol}$ ) was incubated with NADase $(15 \mathrm{ml}, 6 \mathrm{U})$ in Tris- $\mathrm{HCl}(50 \mathrm{ml})$ at $37^{\circ} \mathrm{C}$ for $20 \mathrm{~h}$. The incubation mixture was treated in a similar manner as described above to give $9(254 \mathrm{mg}, 35 \%$ yield $)$ as the ammonium salt. MS: $m / z 638\left(M^{+}-1\right) .{ }^{1} \mathrm{H}$ NMR $\left(\mathrm{D}_{2} \mathrm{O}\right)$ : $\delta 1.91(2 \mathrm{H}, \mathrm{s}), 4.11(2 \mathrm{H}, \mathrm{m}), 4.24(3 \mathrm{H}, \mathrm{br}), 4.37(2 \mathrm{H}$, br q), $4.45(1 \mathrm{H}, \mathrm{t}, J 5.0), 4.50(1 \mathrm{H}, \mathrm{dd}, J 4.0$ and $5.0 \mathrm{~Hz})$, $4.72(1 \mathrm{H}, \mathrm{t}, J 5.0 \mathrm{~Hz}), 5.62(1 \mathrm{H}, \mathrm{d}, J 6.1 \mathrm{~Hz}), 6.08(1 \mathrm{H}$, d, J $5.9 \mathrm{~Hz}), 7.24(1 \mathrm{H}, \mathrm{s}), 7.77(1 \mathrm{H}, \mathrm{s}), 8.20(1 \mathrm{H}, \mathrm{s})$, $8.45(1 \mathrm{H}, \mathrm{s})$. Anal. $\mathrm{C}_{19} \mathrm{H}_{27} \mathrm{~N}_{7} \mathrm{O}_{14} \mathrm{P}_{2} \cdot 2 \mathrm{NH}_{3} \cdot 2 \mathrm{H}_{2} \mathrm{O}: \mathrm{C}, \mathrm{H}$, $\mathrm{N}, \mathrm{P}$.

\footnotetext{
$¥ \mathrm{U}$ is the activity of NADase which will cleave $1 \mu \mathrm{mol}$ of NAD per min.
} 
Histidylglycine adenine dinucleotide (10) A mixture of histidylglycine (82 $\mathrm{mg}, 0.39 \mathrm{mmol})$ and NAD (74 mg, $0.11 \mathrm{mmol})$ was incubated with NADase $(5 \mathrm{ml}, 2 \mathrm{U})$ in Tris- $\mathrm{HCl}(30 \mathrm{ml})$ for $15 \mathrm{~h}$. The incubation mixture was treated in a similar manner as described above to provide $10(26 \mathrm{mg}, 31 \%$ yield $)$ as the ammonium salt. MS: $m / z$ $752\left(\mathrm{M}^{+}-1\right) .{ }^{1} \mathrm{H}$ NMR $\left(\mathrm{D}_{2} \mathrm{O}\right): \delta 4.23(3 \mathrm{H}, \mathrm{br}), 4.3-4.4$ $(6 \mathrm{H}, \mathrm{br}), 4.45(3 \mathrm{H}, \mathrm{br}), 4.59(2 \mathrm{H}, \mathrm{dd}, J 2.8$ and $6.0 \mathrm{~Hz})$, $5.95(1 \mathrm{H}$, dd, $J 2.8$ and $6.0 \mathrm{~Hz}), 5.97(1 \mathrm{H}, \mathrm{d}, J 6.0 \mathrm{~Hz})$, $6.20(1 \mathrm{H}, \mathrm{d}, J 5.8 \mathrm{~Hz}), 7.95(1 \mathrm{H}, \mathrm{s}), 8.08(1 \mathrm{H}, \mathrm{s}), 8.26$ $(1 \mathrm{H}, \mathrm{s}), 8.33(1 \mathrm{H}, \mathrm{s})$. Anal. $\mathrm{C}_{23} \mathrm{H}_{33} \mathrm{~N}_{9} \mathrm{O}_{16} \mathrm{P}_{2} \cdot 2 \mathrm{NH}_{3}$. $2 \mathrm{H}_{2} \mathrm{O}: \mathrm{C}, \mathrm{H}, \mathrm{N}, \mathrm{P}$.

Glycylhistidine adenine dinucleotide (11). Glycylhistidine (348 mg, $1.6 \mathrm{mmol})$ and NAD (376 mg, $0.56 \mathrm{mmol}$ ) were incubated with NADase $(10 \mathrm{ml}, 4 \mathrm{U})$ for $20 \mathrm{~h}$. The resulting mixture was treated in the manner described above to provide 11 (103 $\mathrm{mg}, 27 \%$ yield) as the ammonium salt. MS: $m / z 752\left(M^{+}-1\right) .{ }^{1} \mathrm{H}$ NMR $(\mathrm{D}, \mathrm{O}): \delta$ 4.18-4.26 (3 H, br), 4.28-4.40 (6 H, br), 4.45 (3 H, br), $4.59(2 \mathrm{H}, \mathrm{dd}, J 2.8$ and $6.0 \mathrm{~Hz}), 5.94(1 \mathrm{H}$, dd, $J 2.8$ and $6.0 \mathrm{~Hz}), 5.98(1 \mathrm{H}, \mathrm{d}, J 6.0 \mathrm{~Hz}), 6.20(1 \mathrm{H}, \mathrm{d}, J 5.8 \mathrm{~Hz})$, 7.95 (1 H, s), 8.08 (1 H, s), 8.26 (1 H, s), 8.34 (1 H, s). Anal. $\mathrm{C}_{23} \mathrm{H}_{33} \mathrm{~N}_{9} \mathrm{O}_{16} \mathrm{P}_{2} \cdot 2 \mathrm{NH}_{3} \cdot 2 \mathrm{H}_{2} \mathrm{O}: \mathrm{C}, \mathrm{H}, \mathrm{N}, \mathrm{P}$.

Histidylalanine adenine dinucleotide (12) A mixture of histidylalanine $(80 \mathrm{mg}, 0.35 \mathrm{mmol})$ and NAD $(80 \mathrm{mg}$, $0.12 \mathrm{mmol}$ ) was incubated with NADase $(5 \mathrm{ml}, 2 \mathrm{U})$ for $16 \mathrm{~h}$. The incubation mixture was treated as described above to give $12(19 \mathrm{mg}, 24 \%$ yield $)$ as the ammonium salt. MS: $m / z 766\left(M^{+}-1\right) .{ }^{1} \mathrm{H} \operatorname{NMR}\left(\mathrm{D}_{2} \mathrm{O}\right): \delta 1.34$
(3 H, d, J 7.3 Hz), 4.20-4.26 (3 H, br), 4.28-4.40 (6 H, br), $4.45(3 \mathrm{H}$, br), $4.58(2 \mathrm{H}$, dd, $J 3.0$ and $7.4 \mathrm{~Hz}), 5.95$ $(1 \mathrm{H}$, dd, $J 3.0$ and $6.0 \mathrm{~Hz}), 5.98(1 \mathrm{H}, \mathrm{d}, J 6.0 \mathrm{~Hz}), 6.20$ $(1 \mathrm{H}, \mathrm{d}, J 5.8 \mathrm{~Hz}), 7.94(1 \mathrm{H}, \mathrm{s}), 8.05(1 \mathrm{H}, \mathrm{s}), 8.24$ $(1 \mathrm{H}, \mathrm{s}), 8.32(1 \mathrm{H}, \mathrm{s})$. Anal. $\mathrm{C}_{24} \mathrm{H}_{35} \mathrm{~N}_{9} \mathrm{O}_{16} \mathrm{P}_{2} \cdot 2 \mathrm{NH}_{3}$. $2 \mathrm{H}_{2} \mathrm{O}: \mathrm{C}, \mathrm{H}, \mathrm{N}, \mathrm{P}$.

Acknowledgments. This work was supported in part by a Grant-in-Aid for Special Project Research from Hokkaido University provided by the Japanese Ministry of Education, Science and Culture. The authors thank Ms. Manami Sato for her secretarial assistance.

\section{References}

1. Anderson, B. M. and Kaplan, N. O. J. Biol. Chem. 234 (1959) 1226.

2. Walter, P. and Kaplan, N. O. J. Biol. Chem. 238 (1963) 2823.

3. Tono-oka, S., Tone, Y., Marquez, V. E., Cooney, D. A., Sekikawa, I. and Azuma, I. Bull. Chem. Soc. Jpn. 58 (1985) 309.

4. Tono-oka, S. and Azuma, I. Gazz. Chim. Ital. 121 (1991) 297.

5. Tanuma, S., Kawashima. K. and Endo, H. J. Biol. Chem. 263 (1988) 5485 .

6. Howard, M.. Grimaldi, J. C.. Bazan, J. F., Lund, F. E., Santos-Argumedo, L., Parkhouse, R. M. E., Walseth, T. F. and Lee, H. C. Science 262 (1993) 1056.

7. Kim, H., Jacobson, E. L. and Jacobson, M. K. Science 261 (1993) 1330

8. Zatman, L. J., Kaplan, N. O., Colowick, S. P. and Ciotti, M. M. J. Biol. Chem. 209 (1954) 467.

Received April 20, 1994. 